\title{
13
}

\section{Stakeholder Processes in Marine Spatial Planning: Ambitions and Realities from the European Atlantic Experience}

\author{
Sarah Twomey and Cathal O’Mahony
}

\section{Introduction}

Bordered by two oceans and four seas, the European Union (EU) has the largest maritime territory in the world with marine regions accounting for over five million jobs and generating $40 \%$ of its gross domestic product (GDP) (EC 2017). The EU's political economy is inexorably linked to the marine environment and ensuring the health of marine ecosystems is necessary for the future of ocean biodiversity and sustaining maritime development. The scale and diversity of coastal and marine activities across Europe's regional seas thus present huge challenges for governance and policy frameworks. Governance sets the stage within which management occurs (Olsen 2003) and its success is key to dealing with conflict and escalating pressures on the marine environment. The principles of good environmental governance are well documented: openness; participation; transparency; and, accountability (Wingqvist et al. 2012; Lockwood et al. 2010; Heldaweg 2005). In particular, effective governance goes beyond information provision and consultation by governments; it requires the active participation of stakeholders (Colvin et al. 2016; Reed 2008). Stakeholders represent a host of

\footnotetext{
S. Twomey $(\bowtie) \bullet$ C. O’Mahony

MaREI Centre for Marine and Renewable Energy, Environmental Research Institute (ERI), University College Cork, Cork, Ireland e-mail: s.twomey@ucc.ie 
marine activities operating in the seas comprising diverse statutory, regulatory, commercial and societal perspectives; they are gatekeepers to a vast amount of experience, knowledge, values and interests and play a pivotal role in contemporary marine governance.

Blue Growth is an EU long-term strategy to harness the untapped potential of Europe's oceans, regional seas and coasts for jobs and growth (EC 2012). Specific activities have been earmarked for additional effort-aquaculture, coastal tourism, marine biotechnology, ocean energy and seabed mining. The success of the Blue Growth agenda is contingent on ecosystem health, and current and future activities need to be carefully planned in relation to each other and the surrounding environment (i.e. the ecosystem approach). Marine Spatial Planning (MSP) is recognised as a key mechanism for achieving these goals and applies the ecosystem approach to conduct integrated, forward-looking and strategic decisions on human uses of the sea (Ehler and Douvere 2009).

\section{Aims and Objectives}

This chapter presents a contribution to the MSP literature that is practicebased and is primarily targeted towards planners and a general audience. While the majority of the existing Europe-focused literature has originated from experiences in the semi-enclosed Baltic Sea and the North Sea, this chapter focuses on a selection of coastal nations bordering Europe's Atlantic sea basin-coastal nations which heretofore have not featured prominently in the literature were chosen so as to provide new insight to the challenges along the European Atlantic coastline. The aim of this chapter is to illustrate how different state-based MSP settings affect the type and degree of stakeholder participation in practice. In particular, the focus is on recent trends in stakeholder participation in MSP across different geographic, ecological and socio-political contexts from the island of Ireland (i.e. Ireland and Northern Ireland) and the Iberian coast (i.e. Spain and Portugal). The chapter outlines the complexities and practical challenges associated with the ambitions and realities of delivering multi-sector participatory MSP processes. Insights are drawn from multiple case studies of stakeholder processes including researchbased transboundary MSP pilot projects from the northern and southern European Atlantic, and statutory initiatives at different stages of MSP implementation. 


\section{Methodology}

The methodological approach comprised a desk-study analysis of peer-review and grey literature (e.g. project reports, policy statements) relevant to the EU Atlantic region. The literature analysis included outputs from projects which were informed by activities focused on the engagement of stakeholders through workshops and interviews to ascertain their views and opinions on the implementation of MSP in different jurisdictional settings. Findings to emerge from additional semi-structured interviews with stakeholders engaged in MSP processes, and the recent advancement in implementation, were also incorporated into analysis for this chapter.

\section{$4 \quad$ Conceptualising Stakeholder Processes}

Multiple distinctions relating to the term 'stakeholder' can be found throughout relevant literature. Definitions are not consistently used and can mean numerous things in different management and regulatory contexts (Long 2012). The phrase first emerged in the realm of corporate governance in the 1930s (Preston and Sapienza 1990). In recent decades, it has become widely used in the field of environmental governance and particularly in the marine and maritime sphere (Fig. 13.1).

In MSP, the term 'stakeholder' refers to any individual, group, or organisation that are or will be affected, involved or interested (positively or negatively) and can be classified into the following three broad categories:

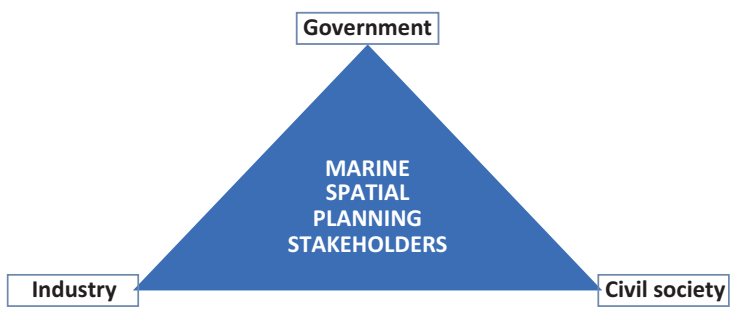

- Government decision-makers at various levels (i.e. government stakeholders including ministries, state agencies, municipalities and local government);

- Commercial or industry stakeholders representing the key marine sectors operating in the area;

- Civil-society stakeholders represented by the research community, citizen and community-based organisations, non-governmental organisations (NGOs), and conservation groups.

Fig. 13.1 Widely accepted definition of stakeholders and their categories in MSP and marine governance (based on Pomeroy and Douvere 2008; Long 2012; Roxburgh et al. 2012; Flannery et al. 2015; Jay 2015, Jay et al. 2016) 
The terms participation, engagement and consultation are regularly used interchangeably to signify a process by which individuals and groups (i.e. stakeholders) converge to communicate, interact, exchange information, provide input or share in decision-making. Although these words are often used synonymously in policy documents and academic literature, they have different meanings. In particular, participation can mean many things to different people. It is frequently used as an umbrella term to describe activities ranging from information provision, public consultation, discussions with the public, or co-decision-making and partnerships.

It is important to take into account that the scope and extent of stakeholder participation differs greatly across regions and from country to country. The level of involvement will also largely depend on the political or legal requirements for participation that already exist in a country or region. In particular, various countries in Europe have used different ways to involve stakeholders in their MSP initiatives (Fig. 13.2).

\section{Institutional Context for Participation in Marine Spatial Planning}

This section outlines they key legal, policy and institutional frameworks that govern contemporary approaches to MSP and the obligations that exist for involving stakeholders.

Early and effective stakeholder participation is a fundamental aspect of the Ecosystem Approach and is also a legal requirement under a host of other different international and European instruments presented in Table 13.1.

The Rio Declaration on Environment and Development (1992) is a document widely regarded as the founding charter of sustainable development. The following principles are of particular relevance: Principle 10 emphasises that environmental issues are best handled with the participation of all concerned citizens; Principle 20 advocates for the full participation of women; while, Principle 22 refers to indigenous peoples and their communities. The Rio conference also led to the approval of Agenda 21, a comprehensive blueprint of action for the twenty-first century to be implemented globally, nationally and locally by UN organisations and the world's governments. The text of Agenda 21 is an extensive 351-page document with multiple references to participation and participatory mechanisms (Charnoz 2009).

Under the Convention on Biological Diversity (CBD), Annex of COP 6 Decision VI/19 specifies the need to ensure the participation of major stakeholders from different sectors in sustainable development and biodiversity 


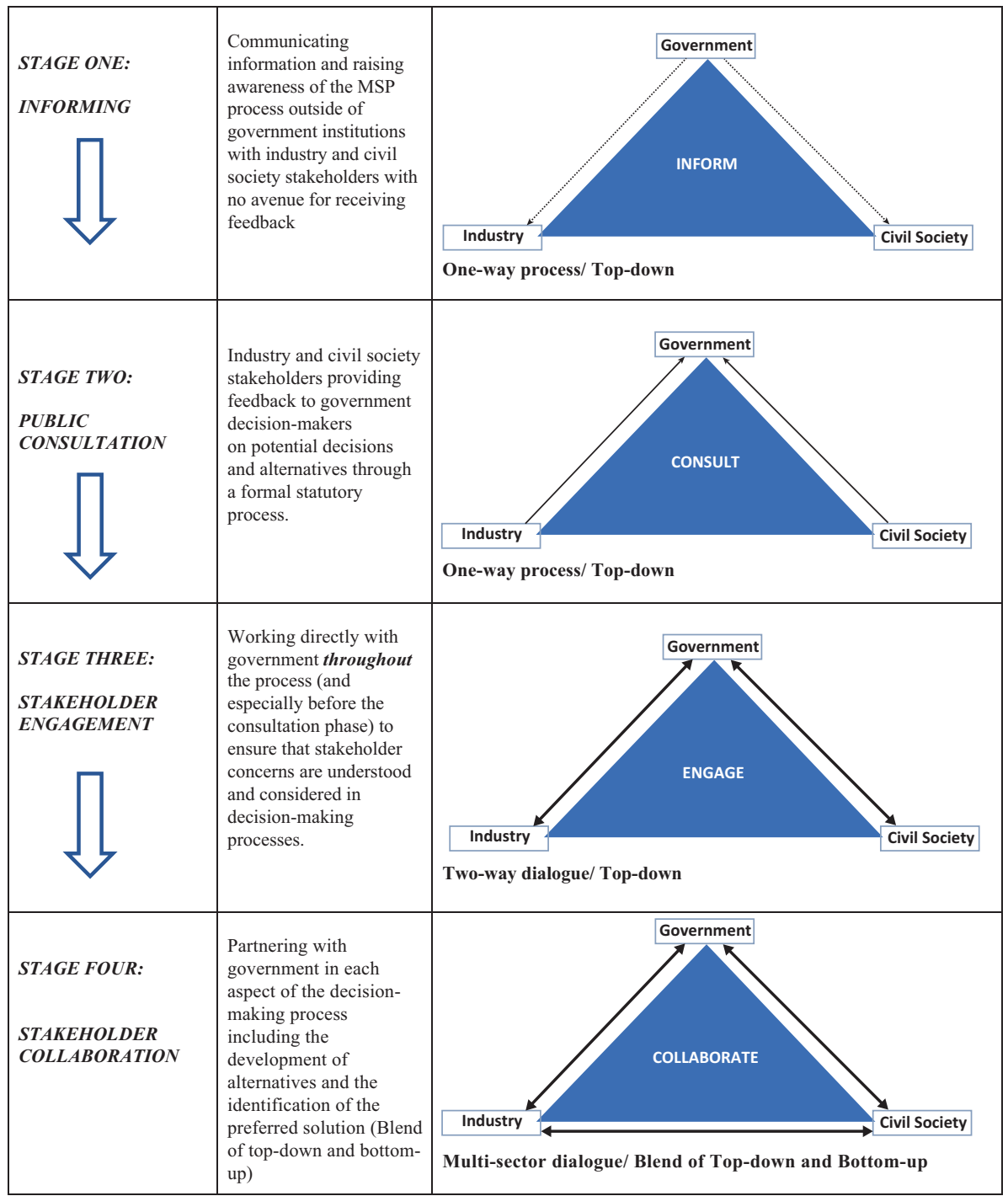

Fig. 13.2 The Continuum of stakeholder participation (using the categories of industry, civil society and government-the latter can include different levels of authority from local, regional to national) in European MSP with various stages ranging from information provision to collaboration between all categories of stakeholders. The arrows represent the flow of information and the direction of interactions between stakeholders (Adapted from Arnstein 1969) 
Table 13.1 List of key international and European instruments relevant to the European Atlantic that require stakeholder participation

\begin{tabular}{ll}
\hline International & European Union \\
\hline Rio Declaration on Environment and & Atlantic Strategy and Action Plan \\
Development (1992) and Agenda 21 & \\
Convention on Biological Diversity (CBD) & $\begin{array}{c}\text { Directive 2014/89/EU on Maritime } \\
\text { Spatial Planning }\end{array}$ \\
OSPAR Convention and the North-East & Directive 2003/4/EC on Public Access to \\
Atlantic Environment Strategy & Environmental Information \\
Aarhus Convention & Directive 2003/35/EC on Public \\
& Participation \\
\hline
\end{tabular}

conservation. The involvement of environmental interest groups and nongovernmental organisations (NGOs) are integral, and the distinct role signposted for NGOs is perhaps the most major innovation of the Convention (Lee and Abbot 2003).

Adopted in 1998 under the auspices of the United Nations Economic Commission for Europe, the Aarhus Convention, is the first comprehensive effort at the supranational level at implementing Principle 10 of the Rio Declaration, providing legally binding obligations on three pillars: public access to environmental information; decision-making; and, justice. The European Community has been a Party to the Aarhus Convention since 2005 and has implemented it via two EU Directives and a Regulation. The Directives address public access to environmental information (Directive 2003/4/EC) and public participation in environmental decision-making (Directive 2003/35/EC). The Regulation (Regulation 1367/2006, hereafter referred to as the Aarhus Regulation) addresses the application of the provisions of the Aarhus Convention, including that enabling NGOs meeting certain criteria to request an 'internal review' of administrative acts or omissions.

Under the EU's MSP Directive (2014/89/EU), MSP is defined as a process by which the relevant Member State's authorities analyse and organise human activities in marine areas to achieve ecological, economic and social objectives (EC 2014). There is a legal obligation to establish and implement MSP plans by 2021 that apply an ecosystem approach; consider economic, social and environmental aspects; and promote the coexistence of relevant activities and uses. Inherent in this is the provision of opportunities for stakeholders to participate throughout the process (Article 6). In addition:

Member States shall establish means of public participation by informing all interested parties and by consulting the relevant stakeholders and authorities, and the public concerned, at an early stage in the development of maritime spatial 
plans, in accordance with relevant provisions established in Union legislation. Member States shall also ensure that the relevant stakeholders and authorities, and the public concerned, have access to the plans once they are finalised (Article 9).

The EC's Communication on Developing a Maritime Strategy for the Atlantic Ocean Area (COM(2011)782) identified a number of themes of relevance to marine stakeholders in the Atlantic sea basin-implementing the ecosystem approach; reducing Europe's carbon footprint; sustainable exploitation of the Atlantic seafloor's natural resources; responding to threats and emergencies; and socially inclusive growth. An Action Plan for a Maritime Strategy in the Atlantic area was subsequently adopted: delivering smart, sustainable and inclusive growth $(\mathrm{COM}(2013) 279)$ which sets out priorities for research and investment to advance the 'blue economy' in the Atlantic area. The Action Plan was developed through consultations conducted in the Atlantic Stakeholder Forum which consisted of representations from each of the five Atlantic Member States, the European Parliament, regional and local authorities, civil society and industry.

\section{MSP Guidance and Recommendations}

MSP aims to achieve multiple objectives (social, economic and ecological) and should therefore reflect as many expectations, opportunities or conflicts occurring in the MSP area. This section summarises (Table 13.2) the conceptual reasons for encouraging stakeholder participation in MSP, which reflect good practice, guidance and associated principles (e.g. EU Roadmap).

According to Principle 4 of the EU Roadmap for MSP (COM(2008)791), in order to achieve broad acceptance, ownership and support for implementation, it is important to involve all stakeholders at the earliest possible stage in the planning process. Stakeholder participation is also reported as a source of knowledge that can significantly improve the quality of MSP (Ehler and Douvere 2009).

Moving towards greater stakeholder participation to holistically address interactions among multiple sectors and communities within coastal and marine areas requires fresh thinking and new approaches. Public consultation alone is no longer appropriate. Implementing effective MSP entails the adoption of inclusive participatory planning processes that move beyond traditional top-down approaches. In addition, a host of guidance documents report that MSP requires active engagement with stakeholders throughout the 
entire planning process from preparatory, drafting and implementation to evaluation phases (e.g. Ehler and Douvere 2009; U.S. Institute for Environmental Conflict Resolution 2011; Pentz 2012; Agardy et al. 2011, 2012).

While the rationale for engagement of stakeholders in MSP is well established (Table 13.2) and is reflected in the guidance documentation available to practitioners, there is a need to consider: firstly, how appropriate are the mechanisms being used and secondly, how different stakeholders react to engagement opportunities is influenced by: the resources and power they have at their disposal, and the design of the actual engagement mechanisms employed in any given situation. Planners should be aware that differences exist between stakeholders in terms of power and influence, and MSP processes should look to mitigate these differences in order to deliver more equitable and democratic approaches (Flannery et al. 2018).

Using the case study material (research-and practice-based) that forms the basis of this chapter, the theoretical considerations on stakeholder participation from the MSP literature are mapped onto each example to illustrate where divergence occurs between theory and practice and the drivers behind this divergence (e.g. geographical, socio-political influences).

Table 13.2 Rationale for actively involving stakeholders in MSP (NOAA Coastal Services Centre 2007; EC 2008; Ehler and Douvere 2009; EC 2014)

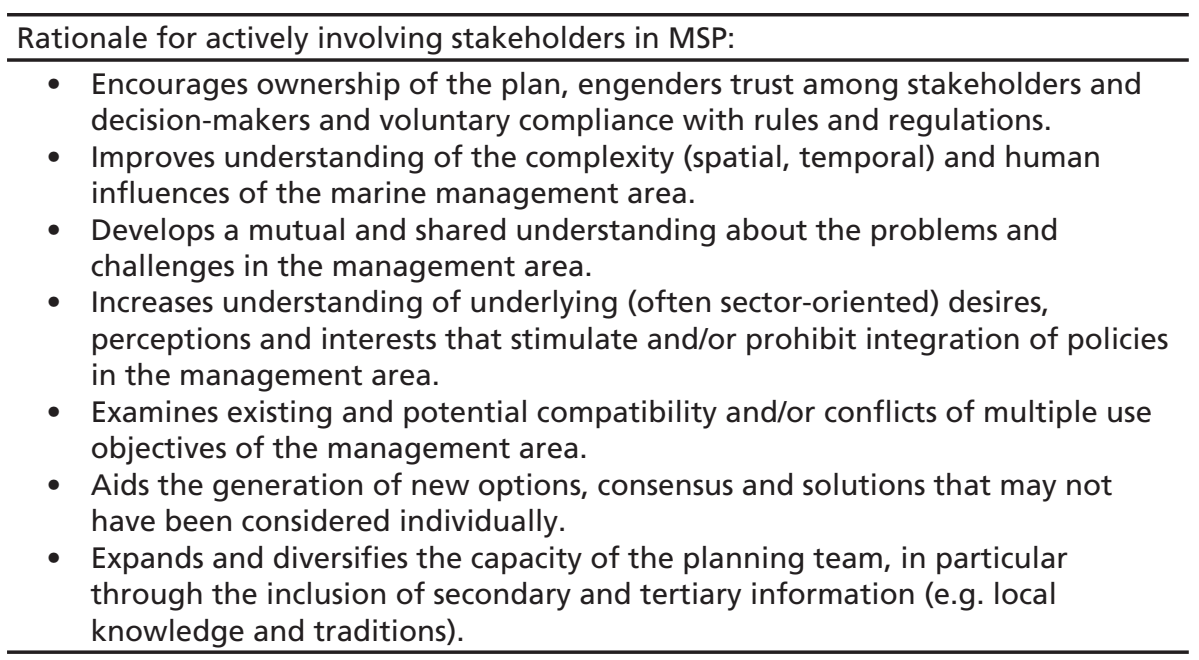




\section{Geographical Context for the European Atlantic Case Studies}

The European Atlantic region (or sea basin) broadly refers to the coasts, territorial and jurisdictional waters of five EU Member States: Ireland; France; Spain; Portugal and, until March 2019, the UK ${ }^{1}$ (i.e. all of Northern Ireland and Wales, the western parts of England and Scotland). Unlike other European marine regions that are somewhat sheltered and semi-enclosed seas, the European Atlantic countries look outwards to an exposed open ocean (Fig. 13.3).

The countries showcased in this chapter are considered as geographically peripheral nations of the EU which in turn provides socio-economic advantages and disadvantages. Ireland, Spain and Portugal have only recently emerged from the economic recession brought about by the European Debt Crisis of 2009. In terms of sea uses, fishing is a major sector within the Atlantic, whilst coastal tourism and shipping are of great importance to all Member States bordering this area. Given the Atlantic region's geographic position, it is considered a gateway to continental Europe (O'Hagan 2018). There is limited oil and gas production, but the region has high potential for the development of offshore renewable energy given its favourable physical and climatic conditions for wind, tidal and wave energy devices (Pérez-Collazo et al. 2015; Magagna and Uihlein 2015).

\section{Stakeholder Processes in Reality}

The following section outlines experiences and outcomes from a researchbased transboundary MSP project with two pilot studies from northern and southern European Atlantic contexts. This is followed by an examination of four statutory initiatives at different phases of MSP implementation in Ireland and Northern Ireland (which is one of the devolved administrations of the UK) on the island of Ireland (Fig. 13.4), and Spain and Portugal on the Iberian coast (Fig. 13.5).

\footnotetext{
${ }^{1}$ Following the results of an EU referendum in 2016, on 29 March 2017, the UK notified the European Council in accordance with Article 50(2) of the Treaty on European Union of their intention to withdraw from the EU in 2019.
} 


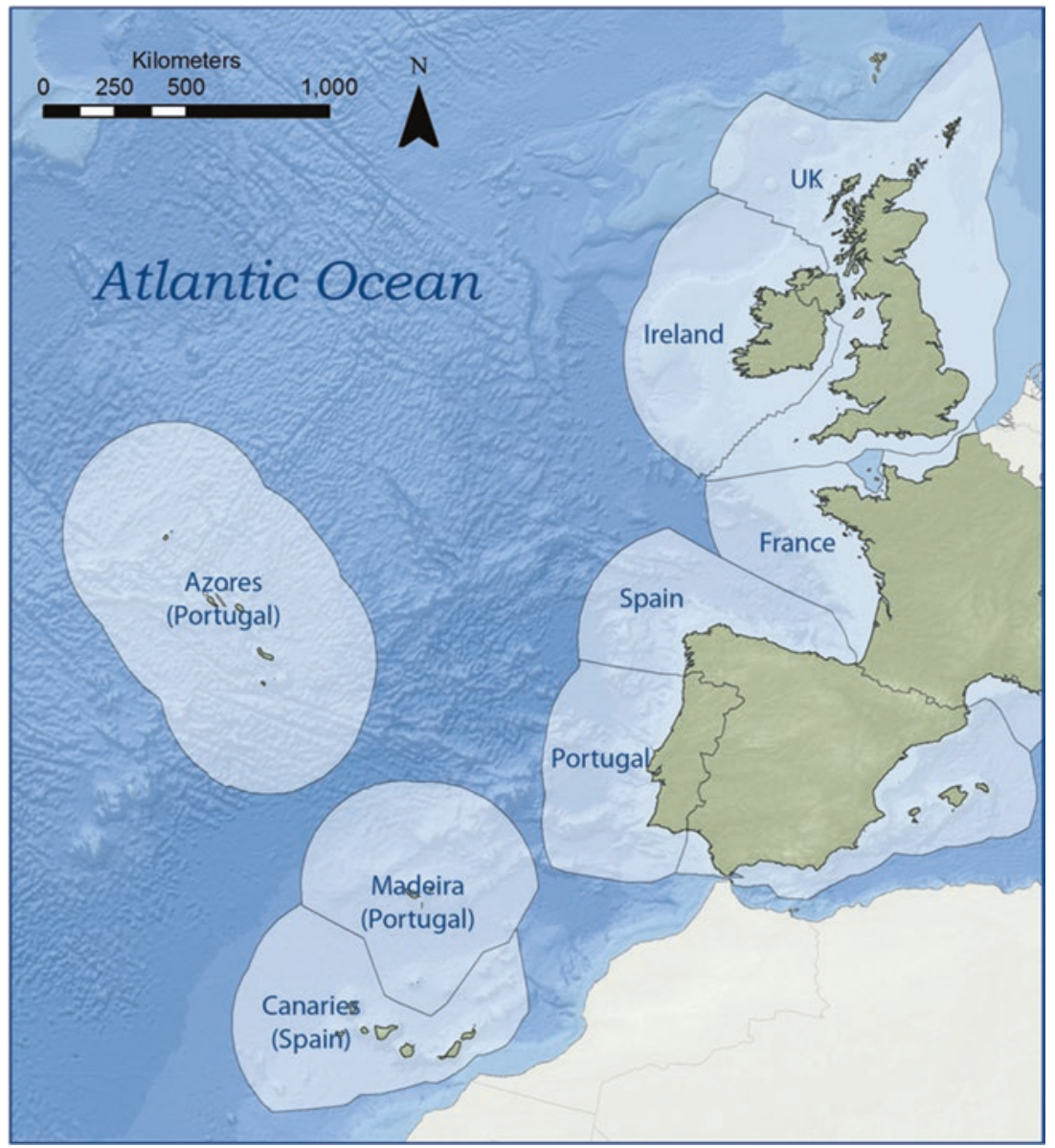

Fig. 13.3 Map of EU Member States bordering the Atlantic Ocean and the extent of their respective Exclusive Economic Zones (EEZs). Data sources: EEA and EMODNET

\subsection{Research-Based Applications}

Although MSP is a national task, the nature of the marine environment and the activities taking place in the sea mean that cooperation in MSP across borders is essential. This is recognised in the MSP Directive, which requires Member States to cooperate with respect to transnational issues with the aim of ensuring that maritime spatial plans are coherent and coordinated across the marine region concerned.

The Transboundary Planning in the European Atlantic (TPEA) project focused on two pilot areas; one on the island of Ireland in the Irish Sea between Ireland and Northern Ireland, UK; the second, in the Gulf of Cadiz between 


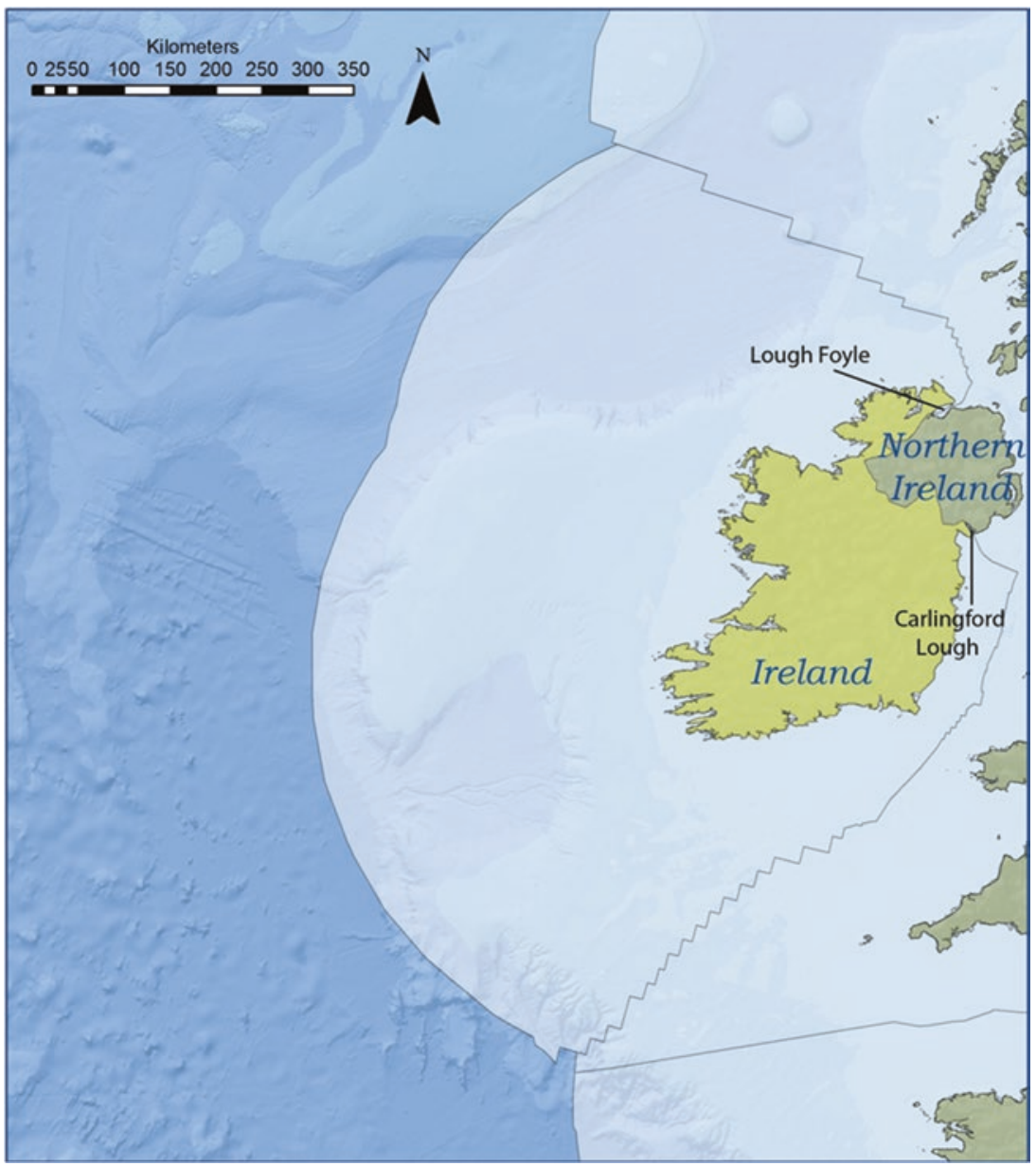

Fig. 13.4 Map of the island of Ireland. Data sources: EEA and EMODNET

Portugal and Spain (Fig. 13.7). It was a civil-society-led project coordinated by a research institution and involved a consortium of six governmental and four research partners across the region. Its primary aim was to explore cross-border (transboundary) MSP exercise and three key pillars provided a framework for planning activities (Jay et al. 2016; Almodovar et al. 2014; TPEA 2013) (Fig. 13.6):

1. Participation of multi-sector stakeholders (from government, industry and civil society groups) throughout the entire process as a means to inform, guide and validate the activities and outputs at all stages of the process (e.g. pre-planning, developing the vision and objectives, establishing the current context, developing scenarios, etc.) (Stage 3 and 4 on the Stakeholder Participation Continuum); 


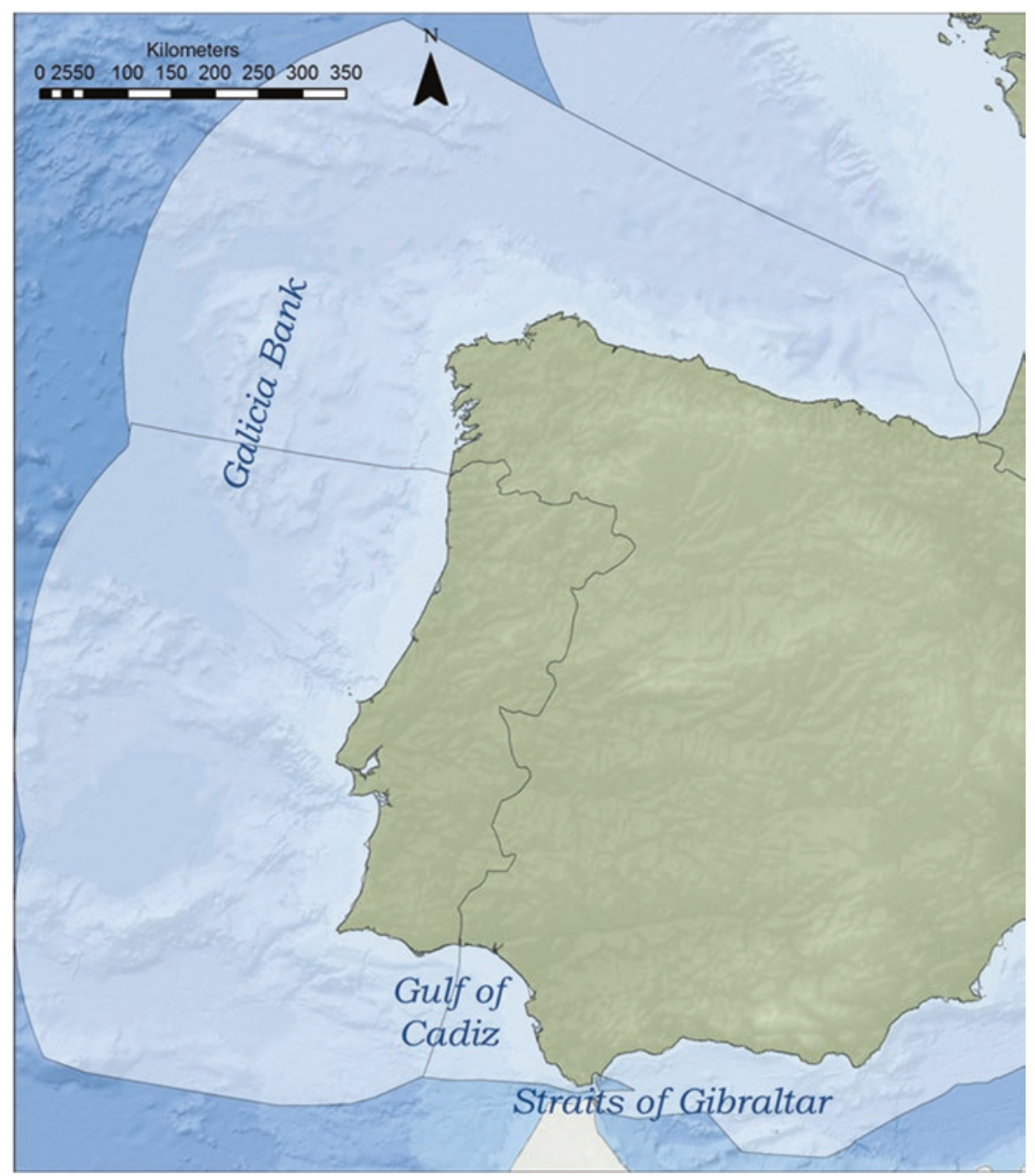

Fig. 13.5 Map of Spain and Portugal with the Iberian coast to the west. Data sources: EEA and EMODNET

2. Analysis of legal, policy and governance frameworks; and

3. Use of Geographic Information Systems (GIS) and geospatial technology.

The authors of this chapter coordinated the stakeholder engagement aspects of the project including the development of a strategy that established the objectives of stakeholder engagement throughout the planning exercise process indicating how and when stakeholders were to be engaged at each stage of the preparation, planning and dissemination process (Fig. 13.7). The central mechanism for participation was the organisation of facilitated stakeholder workshops (three in each pilot area), where participants were invited to explore 


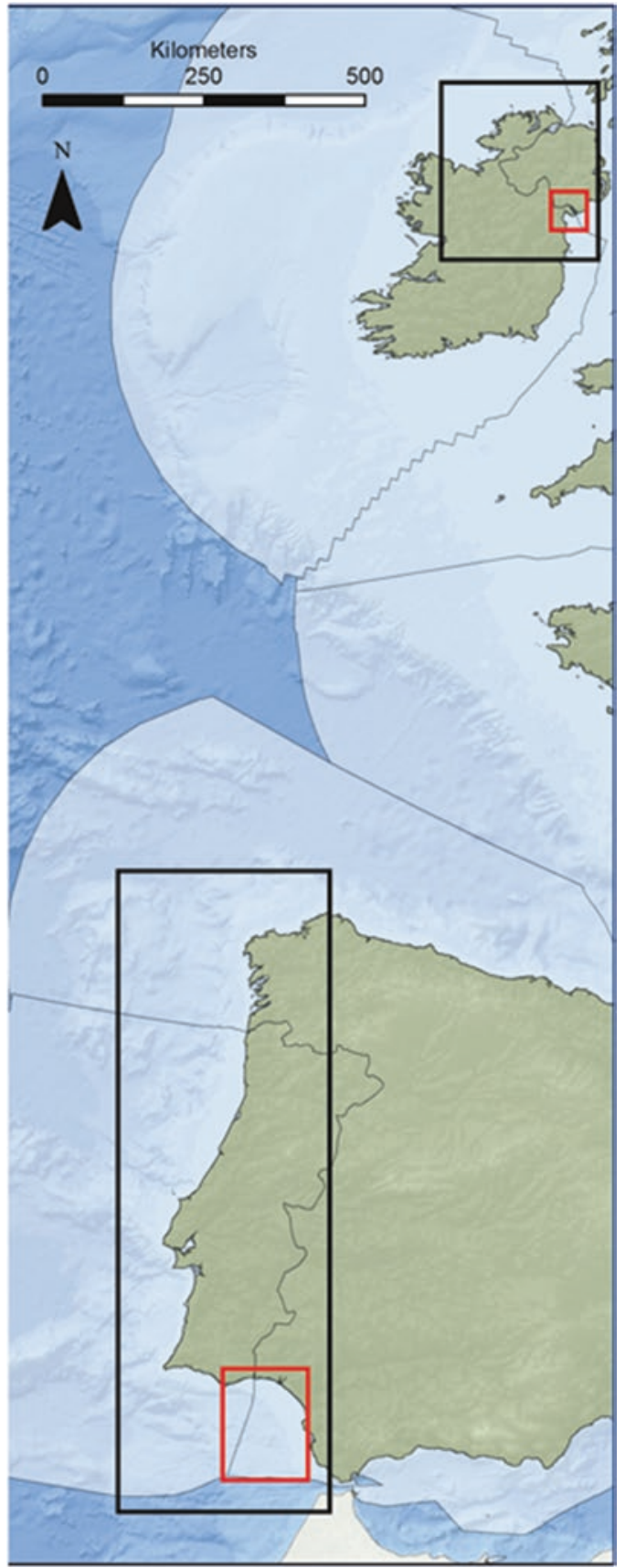

Fig. 13.6 Map illustrating the location of the two MSP pilot areas within the European Atlantic 


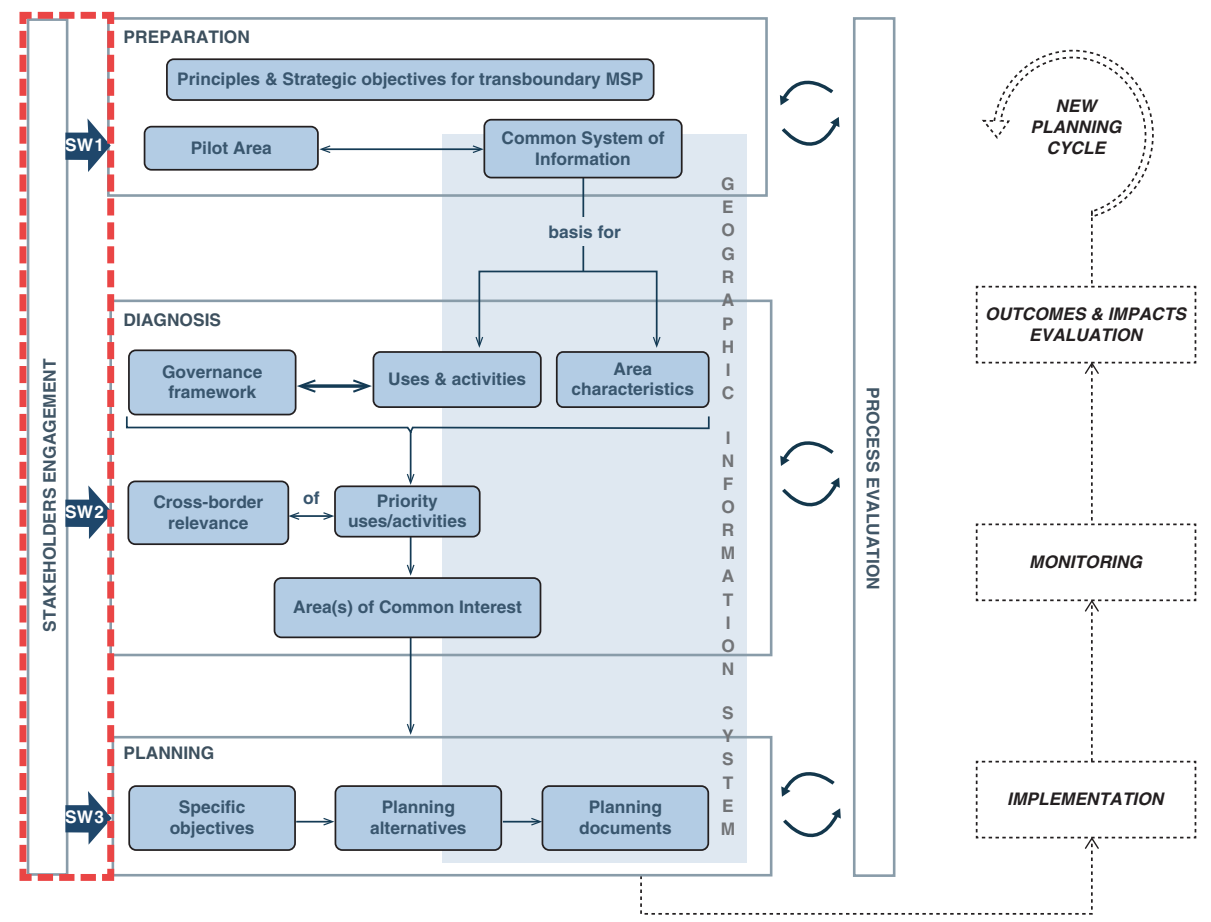

Fig. 13.7 Phases of the MSP planning cycle illustrating how the participation of stakeholders informed the entire process of the TPEA project. (SW=Stakeholder Workshop) (Twomey and O'Mahony 2014)

different aspects of transboundary MSP, and encouraged to share their experiences, expectations, knowledge and opinions. Topics covered during workshops included methods for establishing planning areas; data sharing and harmonisation across jurisdictions; identifying pressures and opportunities; agreeing specific and strategic planning objectives; and development of scenarios (Almodovar et al. 2014).

The TPEA workshops were designed to reflect traditions in stakeholder participation and consisted of presentations, as well as facilitated group work and interactive exercises. In advance of each workshop, TPEA partners planned the format and programme and developed materials specific to the participants and activities on the day-in some cases, materials were provided to participants in advance of the workshop as part of introductory information. Participants were asked to appraise all aspects of each workshop (e.g. content, facilitation), and this information was used to plan subsequent events over the course of the project (Jay 2015; TPEA 2014).

During the first round of workshops, stakeholders were asked to comment on their preferred means of stakeholder engagement and which methods they 
felt would be most appropriate for the MSP process. A variety of methods were proposed-representing the opinions of participants-but also indicating that when embarking on a stakeholder engagement process, planning teams will have to be mindful of the need to tailor messages (e.g. their content and how they are communicated) according to the requirements of different interested parties—either individuals or groups (Table 13.3)

While workshops were an important element of stakeholder participation, they were not the only means of incorporating stakeholder input. Recognising that many stakeholders could make a valuable contribution to the process outside of the workshops, members of the project team actively sought stakeholder input over the course of the project, facilitated through meetings, presentations at industry and NGO events, use of formal and informal networks - this flexible and adaptive approach to engagement ensured the MSP process benefitted from the participation of a wide range of stakeholders across government, industry and civil society.

Some difficulty was experienced in the southern pilot area (Spain and Portugal), particularly in the early stages of the process. For example, despite efforts to ensure equal representation, the first workshop was attended by an overwhelming majority of Portuguese stakeholders. It then became apparent that this situation had transpired as a result of national differences. In 2013, the concept of MSP was largely unknown in Spain coupled with a weaker tradition of public engagement, whereas Portugal had already gained experience of a non-statutory national MSP study (i.e. Planning and Ordering of Maritime Space (POEM)).

Table 13.3 Participatory mechanisms proposed by the TPEA stakeholders and justifications for their use in an engagement process

\begin{tabular}{|c|c|}
\hline $\begin{array}{l}\text { Participatory } \\
\text { Mechanism }\end{array}$ & Justification \\
\hline $\begin{array}{l}\text { Identify organisational } \\
\text { champions }\end{array}$ & $\begin{array}{l}\text { Committed individuals with access to extensive networks } \\
\text { can support engagement efforts of planning team }\end{array}$ \\
\hline Involve politicians & Builds trust and allows for in-depth discussion \\
\hline Use of social media & $\begin{array}{l}\text { Twitter and Linkedln are the new media of choice for many } \\
\text { professionals }\end{array}$ \\
\hline Stakeholder forum & Potential to cater for numerous interest groups \\
\hline Public campaign & Means of raising awareness and encouraging involvement \\
\hline Public meetings & $\begin{array}{l}\text { Provides participants with a voice and an opportunity to } \\
\text { contribute, and for planning team to cover any technical } \\
\text { aspects of plan }\end{array}$ \\
\hline $\begin{array}{l}\text { Visualisation (GIS/MSP } \\
\text { Game) }\end{array}$ & Can be novel tools to initiate and facilitate discussion \\
\hline Online forum & $\begin{array}{l}\text { A means of communicating FAQs and preferred media for } \\
\text { many }\end{array}$ \\
\hline $\begin{array}{l}\text { Roadmap/strategy for } \\
\text { engagement }\end{array}$ & $\begin{array}{l}\text { Sets out where, when and how stakeholders can get } \\
\text { involved }\end{array}$ \\
\hline
\end{tabular}


Although Northern Ireland had already embarked on its statutory MSP process in 2012 (and Ireland had not yet), the challenges experienced in the southern pilot area with stakeholder representation were not shared in the northern pilot area. Perhaps this can be attributed to stakeholders on the island of Ireland sharing a common language in addition to similar traditions of public participation (Table 13.4).

\subsection{Statutory-Based Applications}

This section provides an overview of four case studies of real-life statutory MSP developments from the island of Ireland; Ireland and Northern Ireland, and the Iberian coast; Spain and Portugal. The focus of the analysis is on the aspirations for stakeholder participation and the progress to date (where relevant) as documented by relevant government publications.

Table 13.4 High-level summary of the stakeholder mechanisms employed and trends in representation across different categories of stakeholders at the TPEA multi-sector workshops (2012-2014) in the northern and southern European Atlantic pilot areas

\begin{tabular}{|c|c|c|}
\hline Location & Stakeholder mechanisms employed & Representation \\
\hline \multirow{3}{*}{$\begin{array}{l}\text { Ireland and } \\
\text { Northern } \\
\text { Ireland }\end{array}$} & $\begin{array}{l}\text { Three multi-sector transboundary stakeholder } \\
\text { workshops. }\end{array}$ & $\begin{array}{l}\text { Government: } \\
44 \%\end{array}$ \\
\hline & $\begin{array}{l}\text { Stakeholders were seated in a series of roundtables } \\
\text { (i.e. cabaret style room set-up) to ensure } \\
\text { representatives from different sectors could } \\
\text { interact and hear diverse perspectives on the } \\
\text { topics. Experienced facilitators at each table helped } \\
\text { to guide semi-structured group discussions and } \\
\text { ensure all voices had an opportunity to contribute. }\end{array}$ & Industry: $26 \%$ \\
\hline & $\begin{array}{l}\text { Pro-active outreach and communications with } \\
\text { government, industry and NGO at workshops and } \\
\text { conferences, and government meetings. }\end{array}$ & $\begin{array}{l}\text { Civil Society: } \\
30 \%\end{array}$ \\
\hline \multirow[t]{3}{*}{$\begin{array}{r}\text { Spain and } \\
\text { Portugal }\end{array}$} & $\begin{array}{l}\text { Three multi-sector transboundary stakeholder } \\
\text { workshops. }\end{array}$ & $\begin{array}{l}\text { Government: } \\
72 \%\end{array}$ \\
\hline & $\begin{array}{l}\text { Stakeholders self-selected their own seats around a } \\
\text { U-shape/boardroom style table and the event } \\
\text { followed a formal meeting-style process. The Chair } \\
\text { introduced various topics and asked for feedback } \\
\text { and comments at various points. }\end{array}$ & Industry: $8 \%$ \\
\hline & $\begin{array}{l}\text { Additional single-sector meetings were essential in } \\
\text { Spain to raise awareness of MSP and encourage } \\
\text { attendance. }\end{array}$ & $\begin{array}{l}\text { Civil Society: } \\
20 \%\end{array}$ \\
\hline
\end{tabular}




\section{Ireland}

As an island nation, Ireland has over $7500 \mathrm{~km}$ of coastline and sovereign rights to an Exclusive Economic Zone (EEZ) of $880,000 \mathrm{~km}^{2}$ —over ten times its land mass. Over $50 \%$ of the population reside on the Irish coast, the inshore and offshore waters contain some of the largest fisheries resources in Europe; are the western gateway for shipping to European and international seaports; and are amongst the most valuable and accessible marine renewable resources (wind, wave and tidal) globally.

Legislation Ireland has transposed the Directive through the EU (Framework
for Maritime Spatial Planning) Regulations 2016, signed into law
on 29 June 2016. The competent authority for MSP is the
Department for Housing, Planning and Local Government
(DHPLG).

Status of MSP A Government-led Inter-Departmental Marine Coordination Group was established in $\mathbf{2 0 0 9}$ followed by the launch of a high-level policy document, Harnessing Our Ocean Wealth (HOOW) in 2012. This sets out the vision, high-level goals and key actions to enable Ireland's marine potential to be realised. A roadmap for Ireland's first plan was published in 2017- Towards a Marine Spatial for Ireland.

EU Projects

Stakeholder Participation
TPEA, SIMCELT

HOOW was developed following a period of public consultation in 2012. Over this consultation period, 192 responses were received from a variety of stakeholders including NGOs, Trade and Professional associations, Small or Medium-sized Enterprises (SMEs), Higher Education Institutions and others. The results of this consultation fed into the final version of Harnessing Our Ocean Wealth. Towards a Marine Spatial for Ireland provides details on the proposed public participation and consultation processes from 2018 to 2020 . The aim of this document is to describe how, when and what DHPLG will do with the outcomes of stakeholders' views.

The plan will be guided by the following principles for engaging in MSP:

- involve people early on in the decision-making process and in developing specific policy within the framework provided by HOOW;

- engage with interested people and organisations at the appropriate time using effective engagement methods and allowing sufficient time for meaningful consultation;

- be adaptable, recognising that some consultation methods work better for some people and some issues and that a one-size-fits-all approach will not work;

- respect the diversity of people and their lifestyles and give people a fair chance to have their voice heard regardless of gender, age, race, abilities, sexual orientation, circumstances or wherever they live; 
- be clear in the purpose of any engagement and how stakeholders may contribute and let people know how their views have been taken into account within agreed timescales;

- make documents publicly available on the Department's website; and

- communicate clearly with people using plain English and avoiding jargon.

An Advisory Group has been established to ensure the participation of relevant NGOs, professional bodies and technical experts in the process. In advance of and running alongside subsequent formal public consultation, the DHPLG will also seek to engage stakeholders through the following means: geographic or sector-based groups workshops; web portal; one-to-one meetings; exhibitions and drop-in sessions; attendance at stakeholder meetings; questionnaires; web updates; and, newsletters.

Stakeholder Participation Continuum

Key challenges encountered

Stages 1 and 2 and a plan has been prepared for Stage 3 activities (as of time of writing).

- developing capacity and resources for different forms of stakeholder participation beyond public consultation and information sessions (discussed in interviews) and

- geographical extent of coastline and marine area.

Links

\section{Northern Ireland}

The Marine Plan for the Northern Ireland Plan Area will cover an area of approximately $12,350 \mathrm{~km}^{2}$ and include $650 \mathrm{~km}$ of coastline. A number of large cities and towns are located along the coastline and the marine area is a key asset in terms of biodiversity, recreation, tourism and the transportation of goods and services by sea. The marine waters of Northern Ireland also support industries such as aquaculture and fishing and there is significant potential for economic growth from tidal and offshore wind energy.

\begin{tabular}{l}
\hline Legislation \\
The MSP Directive has been transposed and the competent \\
authority for MSP is the Department of Agriculture, \\
Environment and Rural Affairs (DAERA). In line with the UK's \\
Marine \& Coastal Access Act (2010), the Marine Act (Northern \\
Ireland 2013) sets out a new MSP framework which applies to \\
the inshore region (i.e. the territorial sea out to twelve nautical \\
miles). \\
DAERA are in the process of finalising their first plan. However, \\
whilst the plan exists and has gone through the Sustainability \\
Appraisal process, it is still in draft format and cannot be \\
officially adopted as Northern Ireland has been without a \\
government since February 2017.
\end{tabular}




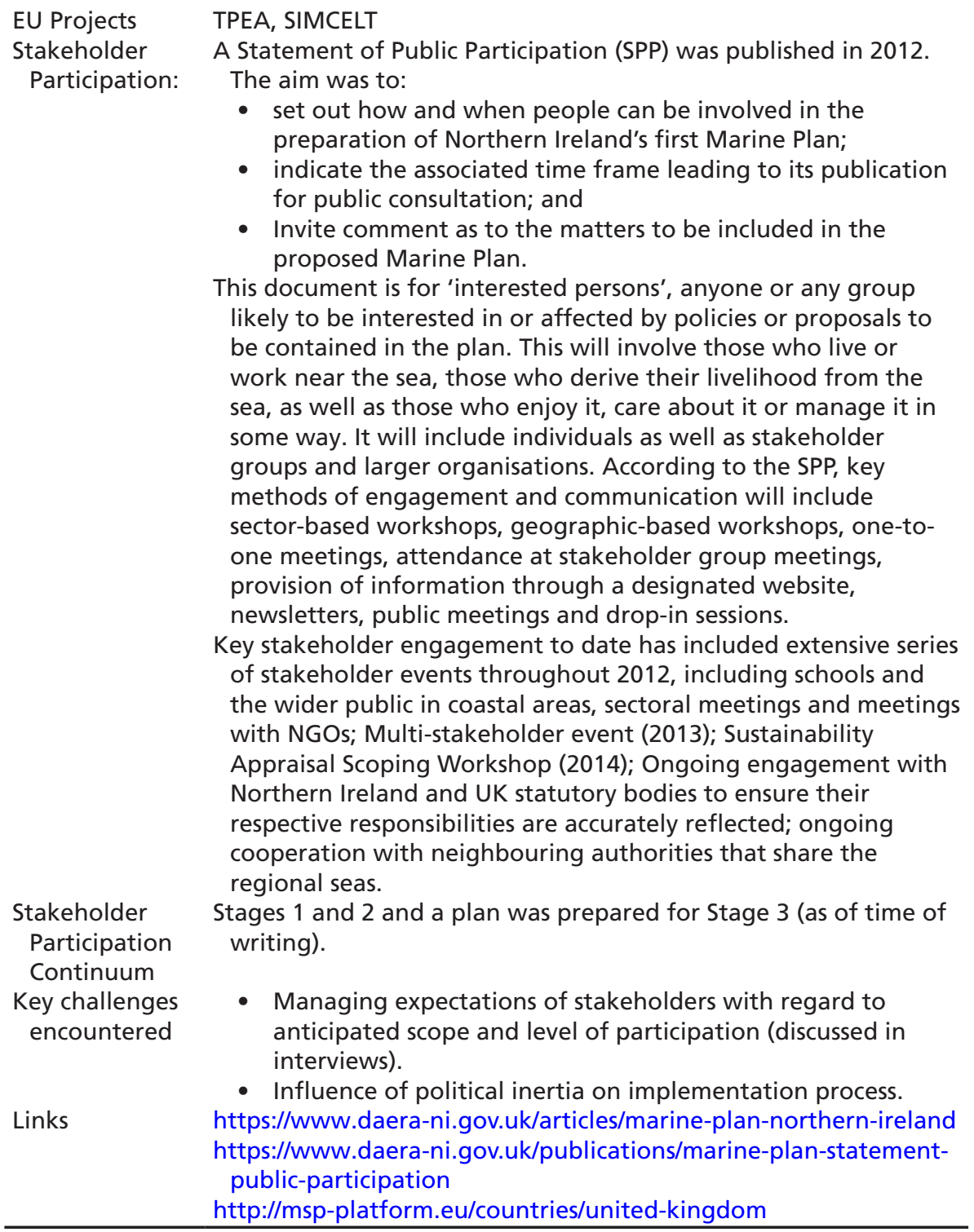

\section{Spain}

Spain has a coastline of over $4680 \mathrm{~km}$ bordering the Atlantic Ocean. The key maritime sectors are coastal and marine tourism, fisheries, maritime transport and mariculture. Plans for offshore wind farms in Spain, the world's fourth largest producer of wind energy, have been set up and will be established in its territorial sea. 


\begin{tabular}{|c|c|}
\hline Legislation & $\begin{array}{l}\text { Spain adopted the Royal Decree 363/2017 on } 8 \text { April } 2017 \\
\text { establishing a framework for MSP. The competent authority has } \\
\text { been designated as the Ministry of Agriculture, Food and } \\
\text { Environment. }\end{array}$ \\
\hline Status of MSP & $\begin{array}{l}\text { Spain has just recently transposed MSP into national law and is } \\
\text { embarking on its preparatory phase for implementation. A } \\
\text { number of MSP-related initiatives (e.g. MPAs, Natura2000, } \\
\text { renewable energy plans) have been carried out, but so far, no } \\
\text { multi-sector MSP initiatives have been developed at the national } \\
\text { level. The focus over recent years has been on the implementation } \\
\text { of the EU's Marine Strategy Framework Directive (MSFD). Marine } \\
\text { strategies are under development for Spain's five marine } \\
\text { subregions to reach the good environmental status of the marine } \\
\text { environment. Each of these subregions will also benefit from MSP. }\end{array}$ \\
\hline EU Projects & SIMNORAT, SIMWESTMED, TPEA, POCTEFEX-ALBORAN \\
\hline $\begin{array}{l}\text { Stakeholder } \\
\text { Participation: }\end{array}$ & $\begin{array}{l}\text { At this stage, it is unclear what opportunities will be available for } \\
\text { stakeholders to participate in Spain's forthcoming process. In } \\
\text { terms of statutory stakeholder involvement, the Inter-Ministerial } \\
\text { Commission on Marine Strategies (CIEM) was created in } 2012 \text { and } \\
\text { is responsible for coordination between Ministerial Departments } \\
\text { of the Central State Administration. Competencies on maritime } \\
\text { and coastal affairs are shared between central and regional } \\
\text { governments, including those facing the Atlantic. According to } \\
\text { the EU MSP Platform, it is likely that stakeholder participation will } \\
\text { be similar to that of the MSFD process, whereby top-down } \\
\text { engagement between high-level government stakeholders was } \\
\text { supplemented with a series of targeted stakeholder workshops } \\
\text { with technical experts from the science community and NGOs. }\end{array}$ \\
\hline $\begin{array}{l}\text { Stakeholder } \\
\text { Participation } \\
\text { Continuum }\end{array}$ & N/A \\
\hline $\begin{array}{l}\text { Key challenges } \\
\text { encountered }\end{array}$ & $\begin{array}{l}\text { - Involving non-statutory stakeholders (e.g. industry, NGOs, } \\
\text { local communities, etc.) in participatory processes for MSP. } \\
\text { - Geographical footprint in multiple sea-basins. }\end{array}$ \\
\hline Links & $\begin{array}{l}\text { http://www.marineplan.es/en/ATLAS_13_06_11_EN.pdf } \\
\text { http://msp-platform.eu/countries/spain }\end{array}$ \\
\hline
\end{tabular}

\section{Portugal}

With an Atlantic coastline of $942 \mathrm{~km}$, Portugal has one of the largest maritime areas in Europe with an EEZ of $1,700,000 \mathrm{~km}^{2}$ encompassing both continental Portugal and two large insular regions surrounding the Azores and Madeira. Traditional economic activities include fishing, aquaculture and maritime transport, whilst new emerging sectors such as deep-sea mining, biotechnology and ocean energy are begin developed. 


\begin{tabular}{|c|c|}
\hline Legislation & $\begin{array}{l}\text { Portugal has approved legislation for MSP for all Portuguese } \\
\text { maritime space. In 2014, the first Portuguese MSP law was } \\
\text { enacted, followed by Order No. } 11494 / 2015 \text { in } 2015 \text { which } \\
\text { paved the way for the development of the Situation Plan, } \\
\text { (Portuguese MSP). The competent authority is the Ministry } \\
\text { of the Sea. }\end{array}$ \\
\hline MSP Status & $\begin{array}{l}\text { From } 2008 \text { to 2012, the government led a (non-statutory) } \\
\text { multidisciplinary MSP study-Planning and Ordering of } \\
\text { Maritime Space (POEM). A new agency was then } \\
\text { established, the Ministry for Agriculture, Sea, Environment } \\
\text { and Spatial Planning (MAMAOT), with responsibility for } \\
\text { both terrestrial planning and MSP. Several agencies were } \\
\text { reorganised or disbanded, including the agency responsible } \\
\text { for the development of POEM. }\end{array}$ \\
\hline EU Projects & TPEA, SIMNORAT, GPS Azores \\
\hline $\begin{array}{l}\text { Stakeholder } \\
\text { Participation: }\end{array}$ & $\begin{array}{l}\text { The draft version of POEM was published online for public } \\
\text { consultation for } 12 \text { weeks in late } 2011 \text {. This was } \\
\text { supplemented by a series of sector-specific workshops that } \\
\text { were also organised in different coastal locations, focusing } \\
\text { on transport and navigation, fisheries and aquaculture, } \\
\text { coastal tourism and leisure, maritime defence and scientific } \\
\text { research. However, the stakeholder process has been } \\
\text { described as 'tokenistic' with very limited public } \\
\text { consultation over a short period despite the complexity of } \\
\text { the plan (Portman 2011; Calado et al. } 2010 \text { ). } \\
\text { The National Ocean Strategy 2013-2020 (NOS) was } \\
\text { developed through public debate following a large number } \\
\text { of public meetings both in mainland Portugal and in the } \\
\text { Autonomous Regions of the Azores and Madeira. Over } 100 \\
\text { contributions were received from public and private } \\
\text { entities and also from civil society. The NOS aims to } \\
\text { promote the 'effective participation of everyone from a } \\
\text { central, regional and local level-involving public and } \\
\text { private entities and civil society as key partners for the } \\
\text { identification and evaluation of threats and pursuing } \\
\text { opportunities, ensuring reflection and production of } \\
\text { strategic thinking' (Government of Portugal 2014: } 56 \text { ). }\end{array}$ \\
\hline $\begin{array}{l}\text { Stakeholder } \\
\text { Participation } \\
\text { Continuum }\end{array}$ & Stages 1 and 2 \\
\hline $\begin{array}{l}\text { Key challenges } \\
\text { encountered }\end{array}$ & $\begin{array}{l}\text { - Absence of a detailed plan for stakeholder } \\
\text { participation. } \\
\text { - Involving industry stakeholders in participatory } \\
\text { processes for MSP (Portman 2011; Calado et al. 2010). } \\
\text { - Geographical footprint in multiple sea-basins. }\end{array}$ \\
\hline Links & $\begin{array}{l}\text { http://www.portugal.gov.pt/pt/ministerios/mm.aspx } \\
\text { http://www.dgpm.mam.gov.pt/Pages/POEM_ } \\
\text { PlanoDeOrdenamentoDoEspacoMarinho.aspx } \\
\text { https://www.dgpm.mm.gov.pt/enm-en } \\
\text { http://msp-platform.eu/countries/portugal }\end{array}$ \\
\hline
\end{tabular}




\section{Comparative Analysis: Stakeholder Processes Across the European Atlantic}

In comparison to other European marine regions such as the Baltic or North Sea, MSP is still in its infancy in the European Atlantic. Whilst it is clear that MSP implementation across the region is at different stages in terms of implementation, some preliminary trends and issues have been identified. At a country level, the general approaches to planning are diverse as a result of varying underlying social and political contexts. MSP in Portugal is currently in its second cycle (although the first plan was more of a research-based exercise and not a statutory plan); Northern Ireland is at the latter stages of preimplementation of its first plan; Ireland has recently embarked on the preparatory stages of their first plan, and Spain has transposed the relevant legislation but has not yet published any further details on their proposed plan. This variance has implications for the comparative analysis of stakeholder processes across the region; however, projects such as TPEA provide empirical evidence that can be used for the purposes of regional assessment.

Even in adjoining jurisdictions, there will be differences of approach to stakeholder participation and representation by sectors, possibly reflecting different political (e.g. political inertia in Northern Ireland) socio-economic conditions (e.g. emergence from recession), cultures and organisational structures. Unlike the government-led statutory processes presented in the previous section, TPEA was a bottom-up civil society-led process which tested a participatory approach to MSP and aimed to employ all four stages on the Continuum of Participation model (Fig. 13.3). An interesting distinction between the two pilot areas was the design of the stakeholder workshops, particularly in terms of the seating arrangements and (non)-use of trained facilitators. On the island of Ireland, stakeholders were seated at a series of round tables with representatives from all different sectors (i.e. government, industry and civil society) to encourage interaction and multi-perspective discussions (consistent with Stages 3 and 4 on the Stakeholder Participation Continuum). This was based on the assumption that the way in which you design stakeholder interactions at an event will inevitably influence the type of input you receive and smaller groups (e.g. six to eight individuals) at a number of round tables is conducive to more inclusive and meaningful conversations between stakeholders. Experienced facilitators were also appointed at each table to guide the group through a series of semi-structured group discussions; ensure that every stakeholder had an opportunity to meaningfully contribute; and no one voice could dominate the group. A more formal 
approach was favoured on the Iberian coast with stakeholders self-selecting their seats in a U-shaped meeting format without the assistance of facilitators.

Resources were specifically assigned to ensure high levels of representation across sectors. Evidence from these research-based case studies indicate that stakeholder representation across different categories was evenly distributed in the Northern Atlantic countries (Table 13.4). Government decision-makers and statutory stakeholders were well represented across all four countries and over-represented in Spain and Portugal (72\%). Civil society stakeholders from NGOs, the science community and local community groups also played an active role (i.e. $30 \%$ in on the island of Ireland and $20 \%$ on the Iberian coast). However, stakeholders from industry have been under-represented, particularly in Spain and Portugal (8\%).

In terms of statutory processes, of those that have published in-depth information on stakeholder participation (i.e. Northern Ireland and Ireland), the planning authorities indeed claim to be moving beyond traditional consultation methods to more inclusive and participatory mechanisms of engagement. According to these policy documents from Ireland, the ambitions for stakeholder participation fall within Stage 3 of the Stakeholder Participation Continuum-(Engagement)—presented in Table 13.2. Portugal has yet to release specific details of their plans for stakeholders but has indicated that they intend to engage with 'everyone from a central, regional and local level'. However, unlike Ireland and Northern Ireland, they have not published any detailed plans (e.g. a Stakeholder Engagement Strategy or SPP) on when and how they will provide these opportunities. Similarly, with Spain, it is unclear at this point whether the planning authority will apply a participatory approach to MSP (Stage 3 of the Stakeholder Participation Continuum) or merely rely on public consultation (Stage 2 of the Stakeholder Participation Continuum) to obtain input from stakeholders.

\section{Key Challenges}

The case studies reveal valuable insights into the complexity and practical challenges associated with delivering multi-stakeholder MSP processes. Whilst acknowledging that the experiential data are limited, the overarching findings indicate that the policy guidance on participation on MSP has been interpreted in different ways across the European Atlantic. As a result, the cases presented in this chapter from research-based pilot exercises to statutory processes demonstrate that there are variable ambitions for participation in 
MSP. This chapter thus contributes a European Atlantic perspective to an emerging body of literature that is critical of the realities of MSP implementation in other parts of the EU and beyond (e.g. Jones et al. 2016; Flannery and Ellis 2016; Flannery et al. 2018).

According to existing MSP theoretical frameworks, once planning authorities follow a step-by-step approach characterised by interactive multistakeholder participation, a strategic plan can determine where and when human activities occur in marine spaces. The European Atlantic case studies indicate that in reality only the research-based initiative employed mechanisms to engage and involve stakeholders at an early stage and continuously throughout the process. Evidence emerging from the interviews and literature indicate that although Northern Ireland and Portugal had policy ambitions to conduct pro-active and inclusive stakeholder processes in line with good practice, in actuality, the approaches to date have not matched the expectations of stakeholders from industry and civil society.

The diverse and often conflicting activities and perspectives of humans are therefore very much at the heart of MSP. Everyone has some type of stake and, in reality, it is primarily a socio-political process which strives to balance the demands of powerful stakeholders with robust scientific data through strategic trade-offs. Despite these high stakes, evidence from both research and statutory initiatives indicate that industry stakeholders have engaged in lower numbers than those representing government and civil society interests. This is a critical point for MSP and is something that needs to be factored into subsequent planning cycles. Perhaps a tailored engagement strategy with this sector is necessary to clarify the value and importance of their role in terms of providing a unique perspective and tacit knowledge from those operating in an offshore setting.

In theory, the greater the scale of the planning area and the more the marine activities that have to be considered, the greater the number of stakeholders that need to be engaged throughout the process. This complexity inevitably adds to costs in both time and financial resourcing for planning authorities. For example, Northern Ireland has the smallest planning area in all of the case studies, yet it has a larger MSP team than that of Ireland and Portugal. 


\section{Practical Recommendations for Planning Authorities}

The following recommendations to address challenges for stakeholder participation in MSP are based on lessons learnt from a synthesis of: the good practice guidelines developed by the TPEA project (Almodovar et al. 2014); discussions with stakeholders in interviews; and findings from the case studies presented in this chapter.

1. Transparency: Mutual respect and fairness with a transparent process was raised as a key starting point for any engagement exercise.

- Transparency needs to extend to the objectives, outcomes, roles, expectations and limits of any MSP process. For some stakeholders who have had no previous experience with MSP, the concept of MSP can be intangible. Sometimes communicating what MSP is not is more important than explaining what it is. Likewise planning authorities should be explicit on what will be involved in the plan, as well as justifying what won't be covered.

- Stakeholder expectations need to be managed. Honesty goes a long way- to avoid potential conflict with stakeholders, be realistic and don't raise expectations by proposing high levels of engagement if you can't deliver on these promises. If it's going to be mostly public consultation, communicate that from the beginning but aim to improve participatory opportunities in future MSP cycles (e.g. by organising single-sector or multi-sector stakeholder meetings and workshops).

2. Early and ongoing inclusive engagement mechanisms: Engagement with stakeholders outside of government organisations should not be an after-thought.

- Develop a comprehensive profile of stakeholder interests and contacts (e.g. in the form of a database) at the earliest possible stage in the process is essential to identify a wide pool of stakeholders before deciding which particular stakeholders that need to be considered and then targeted at different stages when necessary. The sectoral interests and the associated organisations or groups should be shared with stakeholders (e.g. at meetings or workshops) for validation and to plug any gaps in representation across the various sectors. This database needs to be maintained and updated throughout the planning process in order to 
ensure that all relevant stakeholders are being engaged and to avoid a situation where stakeholders have unintentionally been excluded.

- Many planning authorities are familiar with statutory and regulatory stakeholders, but extra consideration needs to be given to identify other key stakeholders such as industry representatives (e.g. traditional sectors, new emerging industries, environmental consultancies, trade unions); the science community including socio-economic researchers, marine social scientists, GIS specialists; and NGOs at the earliest stage (i.e. preparatory phase) in the MSP process.

- Don't expect stakeholders to initiate contact with you. Outreach by the planning authority is essential, for example, by attending industry and NGO events, conferences, community meetings and so on.

- Strive to find a balance between consultation (i.e. one-way communication or no participation) and trying to engage everyone throughout the process (complete participation) is key. This is a difficult task, but it must be the aim in any MSP process.

- The importance of face-to-face contact through interactive workshops should not be underestimated and over-reliance on websites and newsletters should be avoided. Use participation mechanisms that encourage dialogue and interaction between different stakeholder groups such as the facilitated multi-sector workshops outlined in this chapter. Strive to find a balance between consultation (i.e. one-way communication or no participation) and trying to engage everyone throughout the process (complete participation) is key.

- Stakeholders will often need to justify their attendance at MSP meetings or workshops. Dates and locations may not always suit them. Be flexible and promote an open-door policy to allow stakeholders to drop in and out of the process.

\section{Promoting inclusiveness and developing capacity for stakeholders to} participate effectively in the process: A diverse group of stakeholders from different professions and backgrounds should be encouraged but be cognisant of power and resource imbalances.

- In the early stages of MSP, not all stakeholders will be familiar with the concept or what the process entails. MSP and time and resources need to be allocated to raise awareness so that (as much as possible) stakeholders are on a level playing field.

- Technical information should be tailored to different audiences and communicated clearly in basic terms. Communication professionals are 
invaluable resource in these situations as they have the skills to bridge these gap science and policy gaps with different sectors.

- The process needs to be balanced and designed in a manner that ensures overly vocal stakeholders do not have a disproportionate influence over the process. Using facilitators in a workshop setting is a strategy to overcome this imbalance as various strategies can be applied to promote an environment where no one stakeholder can dominate a discussion

\section{Conclusion: Participation Is a Contested Concept That Often Fails to Live Up to Its Promise}

On a theoretical level, the motivation and rationality for the integration of stakeholders throughout the MSP cycle is unquestionable. However, in practice, the case studies presented in this chapter highlight varying degrees of disconnect between the conceptual underpinnings of MSP theory and the realities of recent stakeholder processes in MSP. The ultimate challenge is to map out ways in which the processes and outcomes of stakeholder processes can align more realistically with the policy aspirations of national planning authorities. All countries profess to be implementing inclusive and multidimensional stakeholder processes in addition to long-established mechanisms such as formal public consultation. However, it is clear from the European Atlantic experience that definitions of stakeholder participation, and exactly what it should entail, vary greatly. The true meaning of 'early and effective engagement' seems open to interpretation and sectors have different opinions on how and what it should look like. In order to contribute to the co-production of the knowledge base upon which Marine Plans are developed, rather than just being consulted, it is vital that stakeholders are allowed flexible opportunities to participate in all stages of MSP.

Acknowledgements This material is based upon works supported by Science Foundation Ireland (SFI) under Marine and Renewable Energy Ireland (MaREI) Centre (12/RC/2302). The Open Access fee of this chapter was provided from the same source. 


\section{References}

Agardy, T., Davis, J., Sherwood, K., \& Vestergaard, O. (2011). Taking Steps Toward Marine and Coastal Ecosystem-based Management: An Introductory Guide. https://doi.org/10.17605/OSF.IO/AKH93

Agardy, T., Christie, P., \& Nixon, E. (2012). Marine Spatial Planning in the Context of the Convention on Biological Diversity: A Study Carried Out in Response to CBD COP 10 Decision X/29. Secretariat of the Convention on Biological Diversity.

Almodovar, M., de Armas, D., Lopes Alves, F., Bentes, L., Fonseca, C., Galofré, J., Gee, K., Gómez-Ballesteros, M., Gonçalves, J., Henriques, G., Jay, S., O’Mahony, C., Rooney, A., \& Twomey, S. (2014). TPEA Good Practice Guide: Lessons for Cross-border MSP from Transboundary Planning in the European Atlantic. Liverpool: University of Liverpool.

Arnstein, S. R. (1969). A Ladder of Citizen Participation. Journal of the American Institute of Planners, 35(4), 216-224.

Calado, H., Ng, K., Johnson, D., Sousa, L., Phillips, M., \& Alves, F. (2010). Marine Spatial Planning: Lessons Learned from the Portuguese Debate. Marine Policy, 34(6), 1341-1349.

Charnoz, O. (2009). The Global Discourse on 'Participation' and its Emergence in Biodiversity Protection (No. 83). Working Paper [online]. Retrieved March 20, 2018, from https://www.afd.fr/sites/afd/files/imported-files/083-document-travail-VA.pdf.

Colvin, R. M., Witt, G. B., \& Lacey, J. (2016). Approaches to Identifying Stakeholders in Environmental Management: Insights from Practitioners to Go Beyond the 'Usual Suspects'. Land Use Policy, 52, 266-276.

EC. (2008). Roadmap for Maritime Spatial Planning: Achieving Common Principles in the EU. [online]. Retrieved March 19, 2018, from http://eur-lex.europa.eu/ legal-content/EN/TXT/PDF/?uri=CELEX:52008DC0791\&from=EN.

EC. (2012). Blue Growth Opportunities for Marine and Maritime Sustainable Growth. [online]. Retrieved March 18, 2018, from http://eur-lex.europa.eu/legal content/EN/TXT/PDF/?uri=CELEX:52012DC0494\&from=EN.

EC. (2014). Directive 2014/89/EU of the European Parliament and of The Council of 23 July 2014 Establishing a Framework for Maritime Spatial Planning. [online]. Retrieved March 16, 2018, from http://eur-lex.europa.eu/legal-content/EN/ TXT/PDF/?uri=CELEX:32014L0089\&from=EN.

EC. (2017). Report on the Blue Growth Strategy Towards More Sustainable Growth and Jobs in the Blue Economy. [online]. Retrieved March 18, 2018, from https:// ec.europa.eu/maritimeaffairs/sites/maritimeaffairs/files/swd-2017-128_en.pdf.

Ehler, C., \& Douvere, F. (2009). Marine Spatial Planning: A Step-by Step Approach Towards Ecosystem-based Management. Manual and Guides No 153 ICAM Dossier No 6. Paris: Intergovernmental Oceanographic Commission UNESCO IOC, 99 pp. 
Flannery, W., \& Ellis, G. (2016). Exploring the Winners and Losers of Marine Environmental Governance (Edited Interface Collection). Planning Theory and Practice, 17(1), 121-122.

Flannery, W., Healy, N., \& Luna, M. (2018). Exclusion and Non-participation in Marine Spatial Planning. Marine Policy, 88, 32-40.

Flannery, W., O’Hagan, A., O’Mahony, C., Ritchie, H., \& Twomey, S. (2015). Evaluating Conditions for Transboundary Marine Spatial Planning: Challenges and Opportunities on the Island of Ireland. Marine Policy, 51, 86-95.

Government of Portugal. (2014). National Ocean Strategy: 2013-2020. [online]. Retrieved March 26, 2018, from https://www.dgpm.mm.gov.pt/enm-en.

Heldaweg, M. (2005). Towards Good Environmental Governance in Europe. European Environmental Law Review, 14(1), 2-24.

Jay, S. (2015). Transboundary Marine Spatial Planning in the Irish Sea. Transboundary Marine Spatial Planning and International Law, p. 174.

Jay, S., Alves, F. L., O’Mahony, C., Gomez, M., Rooney, A., Almodovar, M., Gee, K., de Vivero, J. L. S., Gonçalves, J. M., da Luz Fernandes, M., Tello, O., Twomey, S., Prado, I., Fonseca, C., Bentes, L., Henriques, G., \& Campos, A. (2016). Transboundary Dimensions of Marine Spatial Planning: Fostering Interjurisdictional Relations and Governance. Marine Policy, 65, 85-96.

Jones, P. J. S., Lieberknecht, L. M., \& Qiu, W. (2016). Marine Spatial Planning in Reality: Introduction to Case Studies and Discussion of Findings. Marine Policy, 71(September), 256-264.

Lee, M., \& Abbot, C. (2003). The Usual Suspects? Public Participation Under the Aarhus Convention. The Modern Law Review, 66(1), 80-108.

Lockwood, M., Davidson, J., Curtis, A., Stratford, E., \& Griffith, R. (2010). Governance Principles for Natural Resource Management. Society and Natural Resources, 23(10), 986-1001.

Long, R. (2012). Legal Aspects of Ecosystem-based Marine Management in Europe. In Ocean Yearbook. Hijhoff.

Magagna, D., \& Uihlein, A. (2015). Ocean Energy Development in Europe: Current Status and Future Perspectives. International Journal of Marine Energy, 11, 84-104. NOAA Coastal Services Center. (2007). Introduction to Stakeholder Participation. Retrieved April 06, 2018, from https://coast.noaa.gov/data/digitalcoast/pdf/ stakeholder-participation.pdf.

O'Hagan, A. M. (2018). Regulation and Planning in Sea Basins-NE Atlantic. In K. Johnson, G. Dalton, \& I. Masters (Eds.), Building Industries at Sea: 'Blue Growth' and the New Maritime Economy. Gistrup and Delft: River Publishers.

Olsen, S. B. (2003). Frameworks and Indicators for Assessing Progress in Integrated Coastal Management Initiatives. Ocean \& Coastal Management, 46(3-4), 347-361.

Pentz, T. A. (2012). Stakeholder Involvement in MSP. BaltSeaPlan Report, 24. 
Pérez-Collazo, C., Greaves, D., \& Iglesias, G. (2015). A Review of Combined Wave and Offshore Wind Energy. Renewable and Sustainable Energy Reviews, 42, $141-153$.

Pomeroy, R., \& Douvere, F. (2008). The Engagement of Stakeholders in the Marine Spatial Planning Process. Marine Policy, 32, 816-822.

Portman, M. E. (2011). Marine Spatial Planning: Achieving and Evaluating Integration. ICES Journal of Marine Science, 68(10), 2191-2200.

Preston, L. E., \& Sapienza, H. J. (1990). Stakeholder Management and Corporate Performance. Journal of Behavioral Economics, 19(4), 361-375.

Reed, M. S. (2008). Stakeholder Participation for Environmental Management: A Literature Review. Biological Conservation, 141(10), 2417-2431.

Roxburgh, T., Dodds, L., Ewing, J., Morell, T., Sutton, E., Garcia Varas, J. L., Viada, C., Teleki, K., Siciliano, D., Vallet, E., O'Mahony, C., \& Twomey, S. (2012). Towards Sustainability in the Celtic Sea - A Guide to Implementing the Ecosystem Approach Through the Marine Strategy Framework Directive (p. 47). Cardiff: World Wildlife Fund.

TPEA. (2013). Conceptual Framework: Transboundary Planning in the European Atlantic. Retrieved March 20, 2018, from http://www.tpeamaritime.eu/wp/ wpcontent/uploads/2013/09/TPEA_CONCEPTUALFRAMEWORK_FINAL. pdf

TPEA. (2014). Stakeholder Engagement Factsheet. [online]. Retrieved March 20, 2018, from http://www.tpeamaritime.eu/wp/wp-content/uploads/2013/09/ TPEA-Factsheet-Stakeholder-Engagement_Updated_2014.pdf.

Twomey, S., \& O'Mahony, C. (2014). Stakeholder Engagement in Transboundary Maritime Spatial Planning. TPEA Project Showcase: European Maritime Day, Bremen, Germany. [online]. Retrieved September 6, 2018, from http://www. researchgate.net/publication/281092036_Stakeholder_Engagement_in_ Transboundary_Marine_Spatial_Planning.

U.S. Institute for Environmental Conflict Resolution. (2011). Principles for Stakeholder Involvement in Coastal and Marine Spatial Planning. [online]. Retrieved April 04, 2018, from http://projects.ecr.gov/cmspstakeholderengagement/pdf/ PrinciplesforStakeholderInvolvementinCoastalandMarineSpatialPlanning_0.pdf.

Wingqvist, G. O., Drakenberg, O., Daniel Slunge, D., Martin Sjöstedt, M., \& Ekbom, A. (2012). The Role of Governance for Improved Environmental OutcomesPerspectives for Developing Countries and Countries in Transition. Swedish Environmental Protection Agency [online]. Retrieved April 06, 2018, from http:// www.swedishepa.se/Documents/publikationer6400/978-91-620-6514-0. pdf?pid=3823. 
Open Access This chapter is licensed under the terms of the Creative Commons Attribution 4.0 International License (http://creativecommons.org/licenses/by/4.0/), which permits use, sharing, adaptation, distribution and reproduction in any medium or format, as long as you give appropriate credit to the original author(s) and the source, provide a link to the Creative Commons licence and indicate if changes were made.

The images or other third party material in this chapter are included in the chapter's Creative Commons licence, unless indicated otherwise in a credit line to the material. If material is not included in the chapter's Creative Commons licence and your intended use is not permitted by statutory regulation or exceeds the permitted use, you will need to obtain permission directly from the copyright holder. 